\title{
Direct synthesis of lanthanide-containing SBA-15 under weak acidic conditions and its catalytic study
}

\author{
Zhen $\mathrm{Mu}^{\mathrm{a}}$, Jin Jun $\mathrm{Li}^{\text {a }}$, Zheng Ping Hao ${ }^{\mathrm{a}, *}$, Shi Zhang Qiao ${ }^{\mathrm{b}, *}$ \\ ${ }^{a}$ Research Center for Eco-Environmental Sciences, Chinese Academy of Sciences, Beijing 100085, PR China \\ ${ }^{\mathrm{b}}$ Australian Research Council (ARC) Centre of Excellence for Functional Nanomaterials, School of Engineering and Australian Institute for \\ Bioengineering and Nanotechnology, The University of Queensland, Brisbane QLD 4072, Australia
}

Received 12 October 2006; received in revised form 19 October 2007; accepted 1 November 2007

Available online 7 November 2007

\begin{abstract}
Lanthanide ( $\mathrm{Ln}$ including $\mathrm{La}, \mathrm{Ce}$ and $\mathrm{Nd}$ ) containing SBA-15 molecular sieves with molar ratio $\mathrm{Ln} / \mathrm{Si}=0.01-0.2$ were prepared via direct synthesis under weak acidic conditions ( $\mathrm{pH}$ 1.5-3.0). Characterizations of these samples were done by powder X-ray diffraction, $\mathrm{N}_{2}$ adsorption, inductively coupled plasma atomic emission spectrometry (ICP-AES), FT-IR spectroscopy, and diffuse reflectance ultraviolet spectroscopy. All the samples show a highly ordered two-dimensional hexagonal mesostructure. $\mathrm{N}_{2}$ adsorption testifies that all the Ln-containing SBA-15 materials have the type IV isotherms with type $\mathrm{H}_{1}$ hysteresis loop as well as high specific surface area (798$925 \mathrm{~m}^{2} / \mathrm{g}$ ) and narrow pore size distribution. The diffuse reflectance UV-vis, ICP-AES, and the wide-angle XRD spectra show that most of the lanthanide ions are better dispersed in the calcined materials. The Ln-SBA-15 supported Pd catalysts show high catalytic activity in the oxidation of benzene. The results reveal that Ln-SBA-15 materials can be used as potential supports for the catalytic oxidation of VOCs.
\end{abstract}

(C) 2007 Elsevier Inc. All rights reserved.

Keywords: Weak acidic conditions; Mesoporous materials; Rare earth; VOCs; Catalytic oxidation

\section{Introduction}

Since the discovery of MCM-41 materials by Mobil scientists [1], more and more efforts have been focused on the synthesis of mesoporous molecular sieves, such as SBA, HMS [2], FSM-16 [3], KIT-1 [4] and so on. Among all these mesoporous materials, SBA-15 is regarded as one of the most promising materials because of its higher surface area, larger pore size and higher hydrothermal and thermal stability. It is well known that pure silica SBA-15 is inert in catalytic reactions due to the absence of heteroatom activity sites. Therefore, many scientists have attempted to incorporate various atoms, such as $\mathrm{Ti}, \mathrm{V}, \mathrm{Al}, \mathrm{Cr}, \mathrm{Fe}$, into

\footnotetext{
* Corresponding authors. Tel.: +86 1062849194 ; fax: +86 1062923564 (Hao); Tel.: +61 7 33463815; fax: +61 733468836 (Qiao).

E-mail addresses: zpinghao@rcees.ac.cn (Z.P. Hao), shizq@cheque. uq.edu.au (S.Z. Qiao).
}

the framework or disperse them onto the surface of siliceous materials as metal or metal oxides, which can introduce catalytic sites into mesoporous materials [5-13].

Rare-earth elements have been widely used in the field of catalysis. They participate in the stabilization of supports against thermal sintering and enhance the performance of catalysts in storing and releasing oxygen as well as reducing the reaction activation energy. In recent years, lanthanidecontaining porous materials have been reported and have shown good performance in catalysis. Othman and his coworkers have reported the higher decolorization activity of Mn-La/ZSM-5 than Mn/ZSM-5 [14]. Ce-containing MCM-41 shows good catalytic activity for the vapor-phase dehydration of cyclohexanol to cyclohexene and hydroxylation of 1-naphthol with aqueous $\mathrm{H}_{2} \mathrm{O}_{2}$ and tert-butyl hydroperoxide [15]. As we mentioned above, the ordered mesoporous structure and large pore size of SBA-15 are likely more favorable to the diffusion of reactants and 
products. Thus, lanthanide-containing SBA-15 should be regarded as good catalyst candidates for some catalytic reactions.

Preparation of catalysts with well-dispersed isolated metal species is crucial in achieving high activity and selectivity for catalytic reactions. The rare-earth oxides are usually coated on the wall of SBA-15 by the incipient wetness impregnation and grafting methods, which can result in the appearance of bulk metal species, blocking the channels of SBA-15 and affecting its catalytic activity $[8-11,16]$. Thus it is important to introduce an effective method to synthesize dispersed metal or metal oxides-containing SBA-15, such as the co-condensation or direct synthesis methods. Generally, SBA-15 is synthesized under strong acidic conditions, under which it is difficult to introduce the metal ions into the SBA-15 directly due to the difficulties in the formation of the metal-O-Si bonds. Recently, Li and coworkers reported the preparation of highly ordered Fe-SBA-15 under weak acidic conditions [7]. In their work, Fe substituted SBA-15 mesoporous materials with isolated iron species were obtained via simple direct-hydrothermal methods under $\mathrm{pH}$ 1.0-5.6. It has been indicated that iron ions are generally in an isolated state and it is more suitable to prepare highly isolated metal substituted SBA-15 mesoporous materials under acidic conditions, especially if these conditions are weak $[17,6]$. Thus, it is absolutely necessary to make an attempt to prepare dispersed lanthanide-containing SBA-15 using a similar method as reported in Li's paper.

In this work, lanthanide ( $\mathrm{Ln}$ including $\mathrm{La}, \mathrm{Ce}$ and $\mathrm{Nd}$ ) containing SBA-15 mesoporous materials were directly synthesized under weak acidic conditions ( $\mathrm{pH}$ 1.5-3.0). The synthesized materials are characterized by powder X-ray diffraction (XRD), $\mathrm{N}_{2}$ sorption, UV-vis spectra analysis and inductively coupled plasma atomic emission spectrometry (ICP-AES) analysis, and Fourier-transform infrared spectroscopy (FT-IR). The different $\mathrm{Pd}$ supported (support $=$ Ln-SBA-15, Ce-Im-SBA-15, SBA-15 and $\gamma-\mathrm{Al}_{2} \mathrm{O}_{3}$ ) catalysts are further prepared by an incipient wetness method and tested the rate of the catalytic oxidation of benzene.

\section{Experimental section}

\subsection{Materials preparation}

Ln-SBA-15 materials were synthesized using tetraethyl orthosilicate (TEOS) and lanthanum nitrate $\left(\mathrm{La}\left(\mathrm{NO}_{3}\right)_{3}\right.$. $\left.6 \mathrm{H}_{2} \mathrm{O}\right)$, cerium nitrate $\left(\mathrm{Ce}\left(\mathrm{NO}_{3}\right)_{3} \cdot 6 \mathrm{H}_{2} \mathrm{O}\right)$, or neodymium nitrate $\left(\mathrm{Nd}\left(\mathrm{NO}_{3}\right)_{3} \cdot 6 \mathrm{H}_{2} \mathrm{O}\right)$ as the silicon and lanthanide precursors respectively. Non-ionic triblock copolymer surfactant $\mathrm{EO}_{20} \mathrm{PO}_{70} \mathrm{EO}_{20}(\mathrm{P} 123$, Aldrich $)$ was used as the structure-directing agent. Concentrated $\mathrm{HCl}$ solution was used as the acid source.

The typical preparation procedures of Ln-SBA-15 materials are described as follows: $1 \mathrm{~g}$ of $\mathrm{P} 123$ was dissolved into $35 \mathrm{ml} \mathrm{HCl}$ solution under different $\mathrm{pH}$ i.e. 1.5, 2.0, 2.5 or 3.0. Once P123 was completely dissolved, a certain amount of lanthanide nitrates $(\mathrm{Ln} / \mathrm{Si}=0.01-0.2)$ were added to the above $\mathrm{P} 123-\mathrm{HCl}$ solution. Then, $2.3 \mathrm{ml}$ of TEOS was added, followed by the addition of $\mathrm{NH}_{4} \mathrm{~F}(\mathrm{~F} / \mathrm{Si}=0.03)$, which was used to accelerate the hydrolysis rate of TEOS to match that of Lanthanide nitrates. The mixture was stirred vigorously for $2 \mathrm{~h}$ at room temperature and kept under static conditions for $24 \mathrm{~h}$ at $35^{\circ} \mathrm{C}$. The mixture was then transferred into an autoclave and aged for $48 \mathrm{~h}$ at $100^{\circ} \mathrm{C}$. The resulting solid was filtered, washed and dried at $100^{\circ} \mathrm{C}$ for $24 \mathrm{~h}$. The final mesoporous $\mathrm{Ln}-\mathrm{SBA}-15$ products were obtained after calcination at $550{ }^{\circ} \mathrm{C}$ for $6 \mathrm{~h}$. Pure SBA- 15 was prepared with the same method as Ln-SBA-15, except that no lanthanide nitrate was added to the $\mathrm{P} 123-\mathrm{HCl}$ solution.

Pd was loaded on Ln-SBA-15 via the impregnation method with palladium chloride as the precursor. $500 \mathrm{mg}$ of $\mathrm{Ln}-\mathrm{SBA}-15(\mathrm{Ln} / \mathrm{Si}=0.1)$ synthesized at $\mathrm{pH} 2.5$ was added to the palladium chloride solution $\left(\mathrm{PdCl}_{2}\right.$ : $1.25 \mathrm{mg} / \mathrm{ml}$ ) and stirred at $70{ }^{\circ} \mathrm{C}$. The obtained solid was calcined at $500{ }^{\circ} \mathrm{C}$ for $3 \mathrm{~h}$ and then reduced under hydrogen at $480^{\circ} \mathrm{C}$ for $2 \mathrm{~h}$. These catalysts were noted as $\mathrm{Pd} /$ La-SBA-15, Pd/Ce-SBA-15 and Pd/Nd-SBA-15. For comparison, Pd/SBA-15, Pd/Ce-Im-SBA-15 and $\mathrm{Pd} / \gamma-\mathrm{Al}_{2} \mathrm{O}_{3}$ were synthesized using the same method described above. For all the tested catalysts, the percentage of Pd was $0.9 \%$ and expressed as the weight ratio of $W_{\mathrm{Pd}} / W_{\text {Support }}$.

\subsection{Materials characterizations}

XRD patterns were recorded on a SIEMENS D5005D powder diffraction system using $\mathrm{Cu} \mathrm{K} \alpha$ radiation over the range $0.7^{\circ} \leqslant 2 \theta \leqslant 6.0^{\circ}$. Nitrogen adsorption/desorption isotherms were measured at liquid nitrogen temperature, using a NOVA1200 gas sorption analyzer. Prior to the measurements, all samples were degassed under vacuum at $300{ }^{\circ} \mathrm{C}$ for $5 \mathrm{~h}$. The specific surface area, $A_{\mathrm{BET}}$, was determined from the linear part of the BET equation $(P /$ $P_{0}=0.05-0.25$ ). The pore size distribution was derived from the desorption branch of the $\mathrm{N}_{2}$ isotherm using the Barrett-Joyner-Halenda (BJH) method. The total pore volume was estimated from the amount of nitrogen adsorbed at a relative pressure $\left(P / P_{0}\right)$ of ca. 0.99 . The diffuse reflectance UV-vis spectra were collected using a HITACHI UV3000 scanning spectrophotometer. The powder sample was loaded into a quartz cell, and the spectra were collected over the range of $200-800 \mathrm{~nm}$ reference to $\mathrm{BaSO}_{4}$. Infrared spectra were recorded on a Bruker Tensor 27 using DRIFT techniques, scanned from $4000 \mathrm{~cm}^{-1}$ to $400 \mathrm{~cm}^{-1}$. The sample was ground with $\mathrm{KBr}$ and pressed into a thin wafer. The ICP-AES was used to determine the content of lanthanide in the synthesized samples, which was performed on an OPTIMA 2000. Before any measurements were taken, the solid sample was dissolved in dilute $\mathrm{HCl}$ solution with a small amount of HF.

\subsection{Catalytic activity investigation}

Catalytic activity measurement was performed in a continuous flow fixed-bed reactor of $6 \mathrm{~mm}$ ID that was placed 
in a tubular electrical furnace equipped with a temperature programmer. In each test run, $50 \mathrm{mg}$ of catalyst diluted with an appropriate amount of inert quartz beads (4060 mesh) was placed at the center of the reactor, above which a thermocouple was located to monitor the reaction temperatures. To create the steam containing benzene, one stream of pure air was passed through a boat-shaped saturator in an ice bath to produce a mixed gas containing benzene of high concentration, which was further diluted, with another stream of pure air before reaching the reaction bed. The total flow rate was set to be $320 \mathrm{ml} \mathrm{min}^{-1}$ with a concentration of ca. 1000 ppm by adjusting the two flow rates. The gas hourly space velocity (GHSV) in the tests was kept ca. $100000 \mathrm{~h}^{-1}$. An on-line gas chromatograph equipped with a FID detector was used to analyze the concentration of benzene in the inlet and outlet gas. Before each measurement was taken, the temperature of the catalytic bed was raised to $120^{\circ} \mathrm{C}$ under the feed stream and stabilized at that temperature until the concentration of benzene became constant. No conversion of benzene was observed at this temperature. Then the temperature of catalyst bed was raised using a heating rate of $5^{\circ} \mathrm{C} / \mathrm{min}$, and the temperature was kept constant for 2 min at each datum point for equilibrium prior to analyzing the benzene concentration of the outlet gas.

\section{Results and discussion}

\subsection{Effect of $p H$ value}

The acidic environment ( $\mathrm{pH}$ value) of the whole synthesis procedure was variable and influenced by some factors

Table 1

$\mathrm{pH}$ changes during the whole preparation procedure of La-SBA-15

\begin{tabular}{llclllll}
\hline $\begin{array}{l}\text { Sample } \\
\text { no. }\end{array}$ & $\begin{array}{l}\text { Initial } \\
\mathrm{pH}\end{array}$ & $\begin{array}{l}(\mathrm{La} / \mathrm{Si})_{\text {gel }} \\
(\%)\end{array}$ & $\mathrm{pH}^{\mathrm{a}}$ & $\mathrm{pH}^{\mathrm{b}}$ & $\begin{array}{l}d_{100} \\
(\mathrm{~nm})\end{array}$ & $\begin{array}{l}a_{0} \\
(\mathrm{~nm})\end{array}$ & $\begin{array}{l}(\mathrm{La} / \mathrm{Si})^{\mathrm{c}} \text { solid } \\
(\%)\end{array}$ \\
\hline 1 & 1.5 & 5 & 3.05 & 1.54 & 9.5 & 10.9 & 0.52 \\
2 & & 10 & 3.05 & 1.55 & 8.7 & 10.1 & 0.64 \\
3 & & 15 & 3.06 & 1.52 & 9.5 & 10.9 & 0.71 \\
4 & & 20 & 3.05 & 1.54 & 9.6 & 11.1 & 0.85 \\
5 & 2.0 & 5 & 3.24 & 1.92 & 10.6 & 11.2 & 0.58 \\
6 & & 10 & 3.26 & 1.90 & 9.9 & 11.5 & 0.69 \\
7 & & 15 & 3.30 & 1.91 & 9.9 & 11.4 & 0.75 \\
8 & & 20 & 3.22 & 1.89 & 9.7 & 11.2 & 0.84 \\
9 & 2.5 & 5 & 3.92 & 2.56 & 10.5 & 12.1 & 1.23 \\
10 & & 10 & 3.96 & 2.54 & 10.3 & 11.9 & 2.82 \\
11 & & 15 & 3.91 & 2.48 & 10.5 & 12.1 & 3.12 \\
12 & & 20 & 3.92 & 2.48 & 10.5 & 12.1 & 4.22 \\
13 & 3.0 & 5 & 4.51 & 3.05 & 10.3 & 12.0 & 1.85 \\
14 & & 10 & 4.51 & 3.02 & 10.5 & 12.1 & 3.01 \\
15 & & 15 & 4.54 & 3.02 & 10.6 & 12.2 & 4.76 \\
16 & & 20 & 4.39 & 3.01 & 10.5 & 12.1 & 5.23 \\
17 & 4.0 & 10 & 5.36 & 3.35 & - & - & - \\
18 & 5.0 & 10 & 6.42 & 3.38 & - & - & - \\
\hline
\end{tabular}

${ }^{\mathrm{a}}$ The $\mathrm{pH}$ value of $\mathrm{HCl}$-surfactant aqueous solution.

b The $\mathrm{pH}$ value of mixed solution after the addition of metal salt.

${ }^{\mathrm{c}} \mathrm{La} / \mathrm{Si}$ (molar ratio) obtained by the ICP analysis. such as the protonation of the surfactant and the hydrolysis of the metal salt [7]. The changes in $\mathrm{pH}$ in the whole solgel procedure for the synthesis of La-SBA-15 (La/ $\mathrm{Si}=0.05-0.2$ ) are shown in Table 1. Owing to the protonation of surfactant, the initial $\mathrm{pH}$ value of $\mathrm{HCl}$ solution was significantly increased to a higher value $\left(\mathrm{pH}^{\mathrm{a}}\right)$ after the addition of the surfactant. However, after lanthanum nitrate was added, the $\mathrm{pH}^{\mathrm{a}}$ value decreased again to a relative lower value $\left(\mathrm{pH}^{\mathrm{b}}\right)$ due to the hydrolysis of the metal salt. For samples with initial $\mathrm{pH}<3.0$, the $\mathrm{pH}^{\mathrm{b}}$ was almost equal to the initial $\mathrm{pH}$ value of $\mathrm{HCl}$, and the increase in the $\mathrm{La} / \mathrm{Si}$ molar ratios slightly influenced the value of $\mathrm{pH}^{\mathrm{b}}$. When the initial $\mathrm{pH}$ value was 4.0 or 5.0 , the $\mathrm{pH}^{\mathrm{b}}$ was observed to be about 3.4. In order to objectively investigate the effect of $\mathrm{pH}$ on the synthesis of Ln-SBA-15, the $\mathrm{pH}^{\mathrm{b}}$ of the above two cases was further adjusted with $\mathrm{NaOH}$ to 4.0 and 5.0 to keep consistent with their initial $\mathrm{pH}$ values. Fig. 1a shows the XRD patterns of La-SBA-15 (La/ $\mathrm{Si}=0.1)$ synthesized at different $\mathrm{pH}$ values. When the initial $\mathrm{pH}$ value is $1.5-3.0$, La-SBA-15 samples display three well-resolved diffraction peaks, which are typical of the SBA-15 mesoporous materials. Compared with La-SBA15 synthesized at initial $\mathrm{pH}<3.0$, La-SBA-15 synthesized at $\mathrm{pH}^{\mathrm{b}} 3.4$ has poor quality with only one diffraction peak $(100)$ in its XRD patterns (which are not shown in Fig. 1a). When the $\mathrm{pH}^{\mathrm{b}}$ is 4.0 and 5.0, no characteristics peaks can be observed. As it can be seen in Table 1, there exists a relationship between the unit-cell parameter $a_{0}$ and the initial $\mathrm{pH}$, i.e. with an increase in the $a_{0}$ values there is an increase in the initial $\mathrm{pH}$, with a fixed $\mathrm{La} / \mathrm{Si}$ molar ratio. For example, an increase in the initial $\mathrm{pH}$ from 1.5 to 3.0 , the unitcell $a_{0}$ of La-SBA- 15 yielded in $\mathrm{La} / \mathrm{Si}=0.1$ augments from $10.1 \mathrm{~nm}$ to $12.1 \mathrm{~nm}$, as evidenced by the shift of peak (100) to lower $2 \theta$ values shown in Fig. 1. While the change of the $\mathrm{La} / \mathrm{Si}$ molar ratios has no obvious effect on the unit-cell parameter $a_{0}$, at the same the initial $\mathrm{pH}$ does, which can be identified in Fig. 2 and Table 2. The results in Table 1 also show that the content of $\mathrm{La}$ in the solid sample measured by ICP-AES is obviously lower than that in the gel. This indicates that the lanthanide species in the gel cannot be introduced completely into SBA-15 under weak acidic conditions. However, the content of $\mathrm{La}$ in the solid sample increases with the initial $\mathrm{pH}$ from 1.5 to 5.0. This shows that an increase in the initial $\mathrm{pH}$ favors the introduction of more La into SBA-15. But La-SBA-15 with ordered $2 \mathrm{D}$ hexagonal structure can only be obtained when the initial $\mathrm{pH}$ value is between 1.5 and 3.0.

Fig. $1 \mathrm{~b}$ and $\mathrm{c}$ shows the XRD patterns of Ce-SBA-15 and Nd-SBA-15 with a constant $\mathrm{Ce} / \mathrm{Si}$ and $\mathrm{Nd} / \mathrm{Si}$ molar ratio of 0.1 synthesized under different acidic conditions (pH 1.5-3.0). As with La-SBA-15, all Ce-SBA-15 and Nd-SBA-15 samples have typical highly ordered hexagonal structure, indicating that the addition of $\mathrm{Ce}$ and $\mathrm{Nd}$ atoms into SBA-15 does not destroy the characteristic structure of SBA-15. It has also been found that with an increase in the initial $\mathrm{pH}$, the $2 \theta$ peak (100) shifts to a lower value as observed in La-SBA-15. 

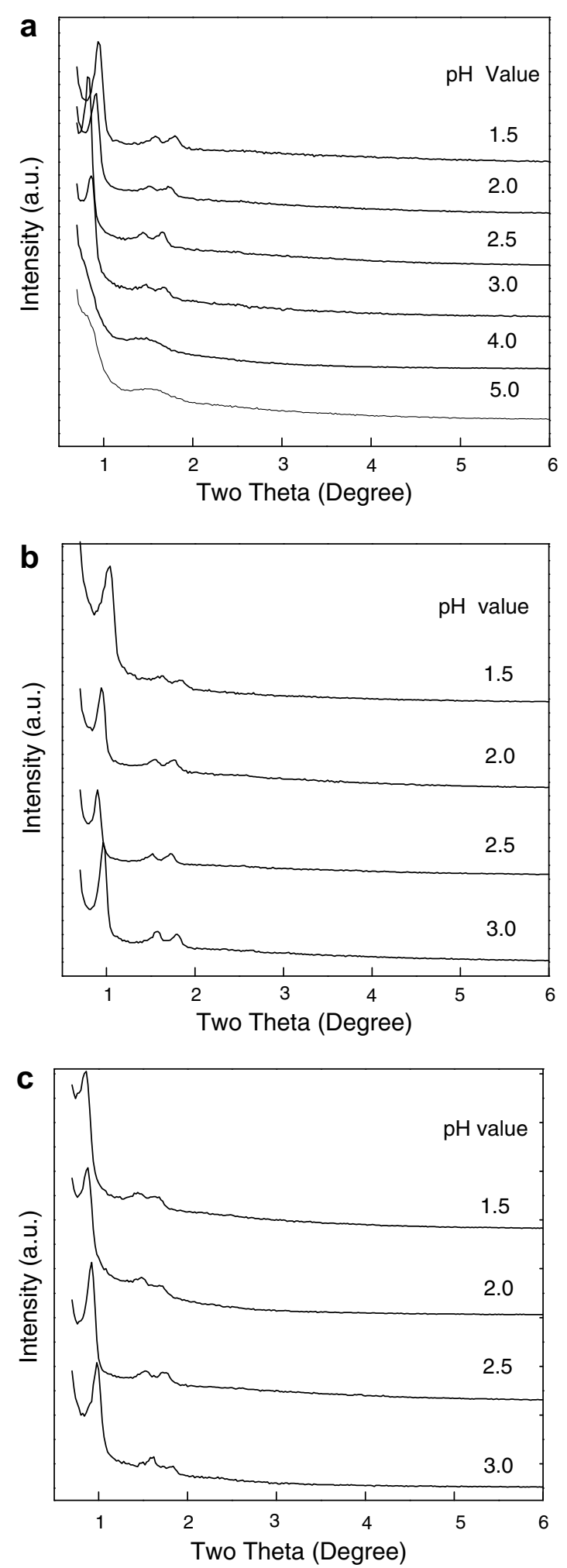

Fig. 1. XRD patterns of Ln-SBA-15 samples synthesized at different $\mathrm{pH}$ with $\mathrm{Ln} / \mathrm{Si}=0.1$ : (a) La-SBA-15; (b) Ce-SBA-15 and (c) Nd-SBA-15.

The $\mathrm{pH}$ value is a decisive parameter in the synthesis of metal substituted SBA-15. When the acidity of the synthesis mixture is higher than the isoelectric point of silica $(\mathrm{pH}$ 2.0), the interaction mechanism between the polymer
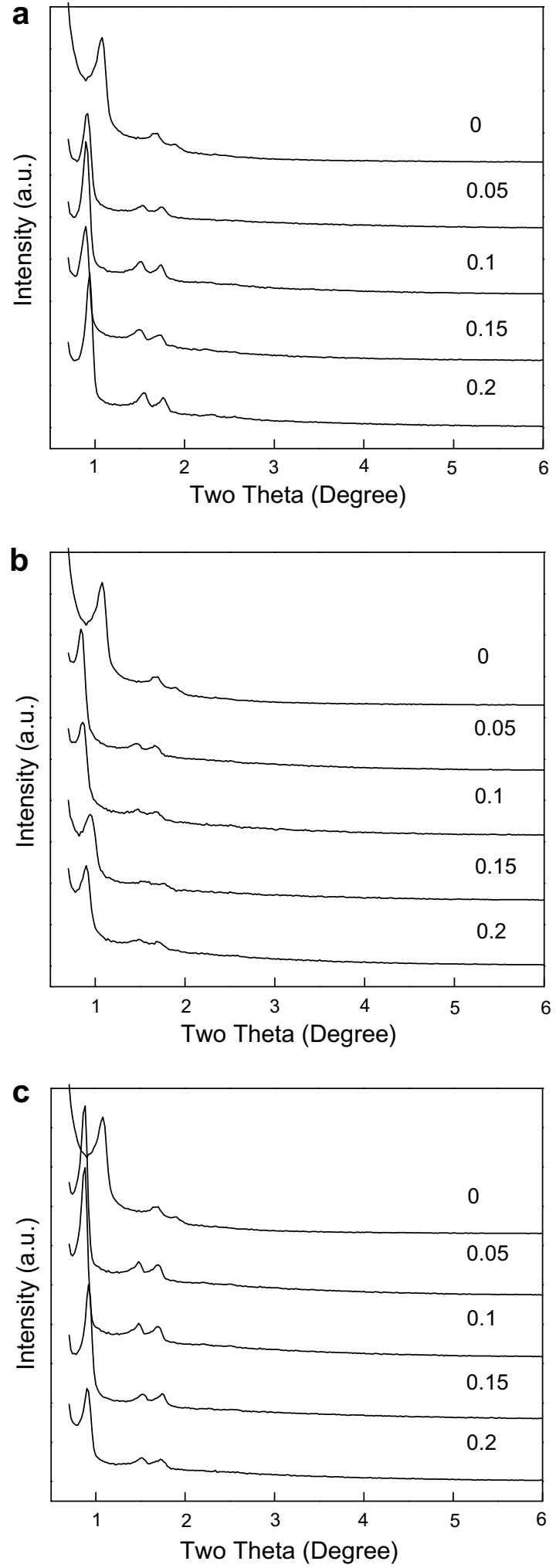

Fig. 2. XRD patterns of Ln-SBA-15 samples with different $\mathrm{Ln} / \mathrm{Si}$ molar ratios synthesized at pH 2.5: (a) La-SBA-15; (b) Ce-SBA-15 and (c) NdSBA-15.

micelle and the silica may be denoted as $\mathrm{S}^{0} \mathrm{H}^{+} \mathrm{X}^{-} \mathrm{I}^{+}$type, where $\mathrm{S}^{0}$ is the non-ionic surfactant, $\mathrm{I}^{+}$is the protonated silicon group and $\mathrm{X}^{-}$is the $\mathrm{Cl}^{-}$supported by $\mathrm{HCl}$. When 
Table 2

Physicochemical properties of Si-SBA-15 and Ln-SBA-15 Materials synthesized at pH 2.5

\begin{tabular}{|c|c|c|c|c|c|c|c|c|c|c|}
\hline Sample & $\begin{array}{l}(\mathrm{Ln} / \mathrm{Si}) \\
\text { input }(\%)\end{array}$ & $\begin{array}{l}(\mathrm{Ln} / \mathrm{Si})^{\mathrm{a}} \\
\text { Output }(\%)\end{array}$ & $\begin{array}{l}\text { Total } S_{\mathrm{BET}}^{\mathrm{b}} \\
\left(\mathrm{m}^{2} / \mathrm{g}\right)\end{array}$ & $\begin{array}{l}\text { Mesopore } S_{\text {BET }} \\
\left(\mathrm{m}^{2} / \mathrm{g}\right)\end{array}$ & $\begin{array}{l}\text { Micropore } S_{\text {BET }} \\
\left(\mathrm{m}^{2} / \mathrm{g}\right)\end{array}$ & $\begin{array}{l}\text { Total } D_{\mathrm{V}}{ }^{\mathrm{c}} \\
\left(\mathrm{cm}_{3} / \mathrm{g}\right)\end{array}$ & $\begin{array}{l}\text { Micropore } \\
D_{\mathrm{V}}\left(\mathrm{cm}^{3} / \mathrm{g}\right)\end{array}$ & $\begin{array}{l}D_{\mathrm{P}}^{\mathrm{d}} \\
(\mathrm{nm})\end{array}$ & $\begin{array}{l}a_{0}^{\mathrm{e}} \\
(\mathrm{nm})\end{array}$ & $\begin{array}{l}W^{\mathrm{f}} \\
(\mathrm{nm})\end{array}$ \\
\hline SBA-15 & - & - & 362 & 275 & 87 & 1.1 & 0.07 & 7.05 & 10.5 & 3.5 \\
\hline La-SBA-15 & 5 & 1.23 & 798 & 574 & 224 & 1.1 & 0.12 & 6.4 & 12.1 & 5.7 \\
\hline La-SBA-15 & 10 & 2.82 & 865 & 584 & 281 & 1.1 & 0.13 & 6.2 & 11.9 & 5.7 \\
\hline La-SBA-15 & 15 & 3.12 & 823 & 549 & 274 & 1.2 & 0.11 & 6.5 & 12.1 & 5.6 \\
\hline La-SBA-15 & 20 & 4.22 & 835 & 580 & 255 & 1.1 & 0.12 & 6.6 & 12.1 & 5.5 \\
\hline Ce-SBA-15 & 5 & 1.42 & 894 & 643 & 251 & 1.2 & 0.11 & 6.6 & 11.8 & 5.2 \\
\hline Ce-SBA-15 & 10 & 3.05 & 925 & 660 & 265 & 1.2 & 0.12 & 6.5 & 12.1 & 5.6 \\
\hline Ce-SBA-15 & 15 & 3.78 & 864 & 630 & 234 & 1.2 & 0.11 & 6.5 & 12.1 & 5.6 \\
\hline Ce-SBA-15 & 20 & 4.21 & 861 & 596 & 215 & 1.2 & 0.10 & 6.6 & 11.9 & 5.3 \\
\hline Nd-SBA-15 & 5 & 1.22 & 900 & 633 & 267 & 1.2 & 0.12 & 6.4 & 11.7 & 5.3 \\
\hline Nd-SBA-15 & 10 & 2.95 & 857 & 603 & 254 & 1.2 & 0.12 & 6.6 & 11.7 & 5.1 \\
\hline Nd-SBA-15 & 15 & 3.24 & 889 & 625 & 274 & 1.2 & 0.12 & 6.2 & 11.3 & 5.1 \\
\hline Nd-SBA-15 & 20 & 4.15 & 850 & 597 & 253 & 1.1 & 0.12 & 6.6 & 11.5 & 4.9 \\
\hline
\end{tabular}

${ }^{\text {a }} \mathrm{Ln} / \mathrm{Si}$ (molar ratio) obtained by the ICP analysis.

b BET specific surface area.

c Total pore volumes were obtained at $P / P_{0}=0.99$.

d BJH pore diameter calculated from the desorption branch.

e $a_{0}$ calculated by $d_{100}, a_{0}=2 \times d_{100} / \sqrt{3}$.

${ }^{\mathrm{f}}$ Wall thickness $=a_{0}-D p$.

the acidity of the synthesis mixture is higher than the isoelectric point of silica, the interaction mechanism should be the $\mathrm{S}^{0} \mathrm{H}^{+} \mathrm{I}^{-}$type. When the initial $\mathrm{pH}<3.0$, inorganic species interact with protonated surfactant (P123) through the above two mechanisms. Large amounts of inorganic species aggregates around the polymer micelle. As a result, the concentration of inorganic species at the interface between the micelle and the solution is higher than that in solution, which facilitates further polymerization of inorganic species. According to cooperative formation mechanism [18], the polymerization of inorganic species can promote the formation of an ordered micelle crystal phase. When the initial $\mathrm{pH}>3.0$, the interaction between the surfactant and inorganic species becomes weak, thus inhibiting the polymerization of inorganic species. Consequently, the low degree of polymerization leads to the formation of an orderless micelle crystal phase.

\subsection{Effect of $\mathrm{Ln} / \mathrm{Si}$ ratio}

Fig. 2 shows the XRD patterns of the Ln-SBA-15 samples with different $\mathrm{Ln}(\mathrm{La}, \mathrm{Ce}, \mathrm{Nd}) / \mathrm{Si}$ molar ratios synthesized at $\mathrm{pH}$ 2.5. Three well-resolved diffraction peaks of all the samples, indexed as the (100), (110), (200) diffractions, reflect the two-dimensional hexagonal mesostructure with a space group of $p 6 \mathrm{~mm}$ symmetry. With different heterogeneous atoms ( $\mathrm{La}, \mathrm{Ce}, \mathrm{Nd})$, the $2 \theta$ values of peak $(100)$ shift to a lower value compared with that of pure SBA-15, indicating that the unit-cell $a_{0}\left(a_{0}=2 d_{100} / \sqrt{3}\right)$ increases after the incorporation of the lanthanide ions. As others have previously reported $[15,19]$, the lengths of $\mathrm{Ce}-\mathrm{O}$ and $\mathrm{La}-\mathrm{O}$ bonds are larger than that of $\mathrm{Si}-\mathrm{O}$ bond, thus their incorporation into the framework of MCM-41 may increase the unit-cell parameter $a_{0}$. Other scientists have also reported similar observations with different metal ions incorporated into SBA-15 [20]. Hence, we can infer that the lanthanide ions ( $\mathrm{La}, \mathrm{Ce}, \mathrm{Nd}$ ) have been incorporated into the framework of SBA-15. Moreover, the intensities of the XRD peaks of Ln-SBA-15 materials are greater than that of the pure silica SBA-15 sample, which may be attributed to the catalysis of the nitrate ions (from the Ln source) to the condensation of silica species that can assist the formation of a well-ordered structure $[21,22]$. However, the long-range ordering of Ce-SBA-15 and Nd-SBA-15 is gradually lost with an increase in $\mathrm{Ce} / \mathrm{Si}$ and $\mathrm{Nd} / \mathrm{Si}$ molar ratios. This may be due to an increasing number of defect sites and bond strain of these materials that is evidenced by the decreasing intensities of the (100) peak [15].

The structural properties of Ln-SBA-15 were measured by $\mathrm{N}_{2}$ sorption. Here Ce-SBA-15 synthesized with different $\mathrm{Ce} / \mathrm{Si}$ ratios at $\mathrm{pH} 2.5$ are taken as examples and their nitrogen sorption isotherms and pore size distributions are given in Figs. 3a and 3b. A peculiar two-step behavior is observed on the hysteresis loop of all the Ce-SBA-15 samples with $\mathrm{Ce} / \mathrm{Si}=0.02-0.2$ presented in Fig. 3a. The empty mesopores behave like cylindrical mesopores with a hysteresis loop at higher relative pressures $\left(P / P_{0}=0.6\right)$ [23], whereas the mesopores with cerium oxide particles inside behave like ink bottle type mesopores with a hysteresis loop that closes around at a relative pressure of ca. 0.4. The hysteresis loop at ca. 0.4 can still be explained by the fact that SBA-15 contains micropores [24]. The textural properties of Ln-SBA-15 and pure SBA-15 are shown in Table 2. All the Ln-SBA-15 samples synthesized at $\mathrm{pH}$ 2.5 have relatively higher specific surface area (798$925 \mathrm{~m}^{2} / \mathrm{g}$ ) than pure SBA-15 synthesized at the same condition $\left(362 \mathrm{~m}^{2} / \mathrm{g}\right)$, which is essentially due to the larger mesopore $S_{\text {BET }}$ of Ln-SBA-15 samples $\left(549-660 \mathrm{~m}^{2} / \mathrm{g}\right)$ than that of pure SBA-15 $\left(275 \mathrm{~m}^{2} / \mathrm{g}\right)$. This may be ascribed to the enhancement in the long-range ordering of the mate- 


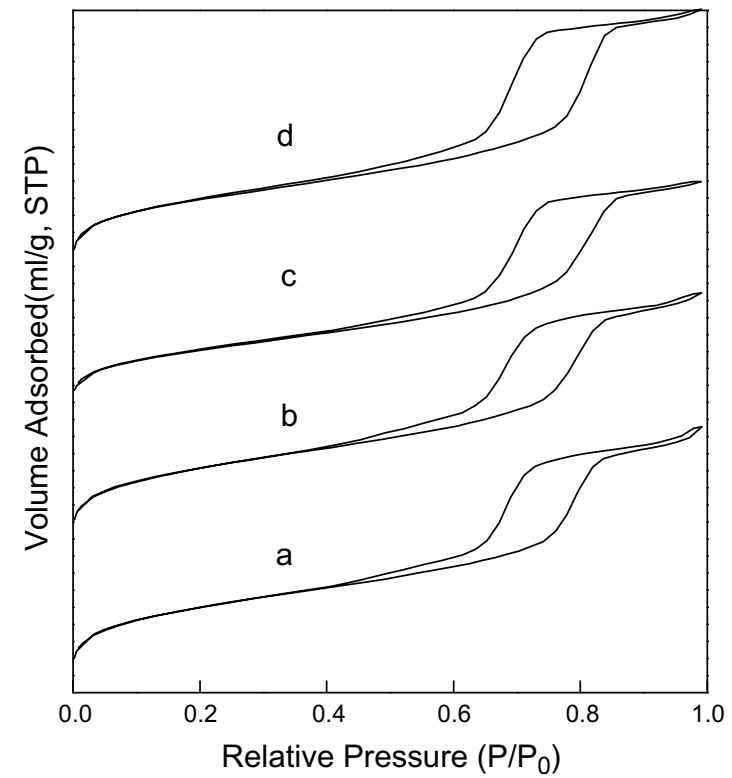

Fig. 3a. Nitrogen adsorption-desorption isotherm of Ce-SBA-15 samples synthesized at $\mathrm{pH} 2.5$ with different $\mathrm{Ce} / \mathrm{Si}$ molar ratio: (a) $\mathrm{Ce} / \mathrm{Si}=0.02$; (b) $\mathrm{Ce} / \mathrm{Si}=0.05$; (c) $\mathrm{Ce} / \mathrm{Si}=0.1$ and (d) $\mathrm{Ce} / \mathrm{Si}=0.2$.

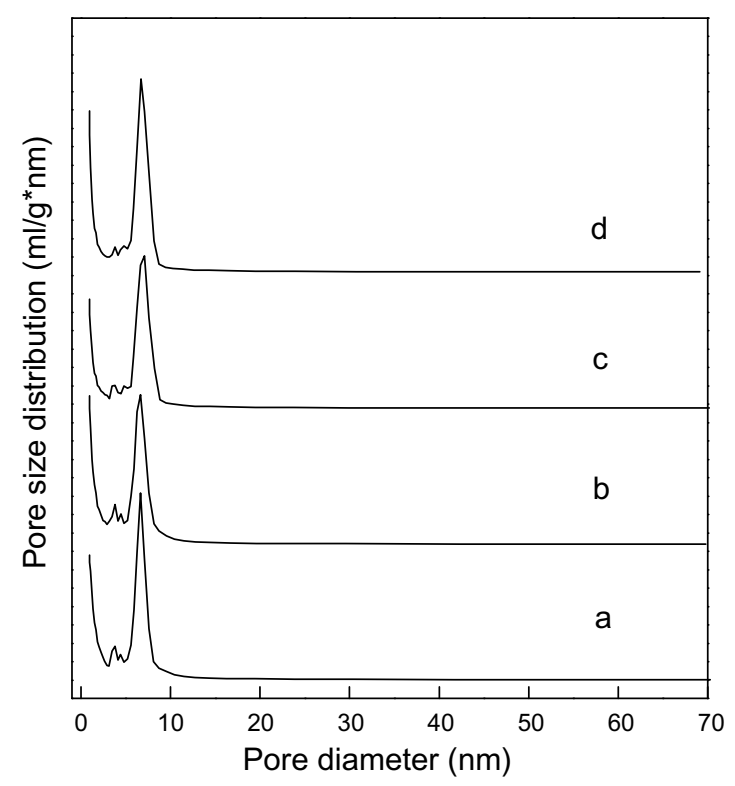

Fig. 3b. Pore size distribution of Ce-SBA-15 samples synthesized at $\mathrm{pH}$ 2.5 with different $\mathrm{Ce} / \mathrm{Si}$ molar ratio: (a) $\mathrm{Ce} / \mathrm{Si}=0.02$; (b) $\mathrm{Ce} / \mathrm{Si}=0.05$; (c) $\mathrm{Ce} / \mathrm{Si}=0.1$ and $(\mathrm{d}) \mathrm{Ce} / \mathrm{Si}=0.2$.

rials induced by the salt effect after the addition of the $\mathrm{Ln}$ precursor. Compared with pure SBA-15, the pore volumes of Ln-samples reduce slightly, whereas the pore diameters of Ln-SBA-15 samples decrease from $7.0 \mathrm{~nm}$ to $\sim 6.2 \mathrm{~nm}$. Hence, Ln-SBA-15 materials have a larger wall thickness because they have larger $a_{0}$ values calculated from above XRD results. For all the Ln-SBA-15 materials, it seems that the variation of the $\mathrm{Ln} / \mathrm{Si}$ molar ratios from 0.05 to 0.2 have little influence on the pore size and pore volume.
Since SBA-15 is typically known to have considerable micropores that originate from the corona of the silica wall, it will be interesting to observe the changes of the micropore structure after the incorporation of Ln ions in the silica matrix. Under normal conditions of preparation of SBA-15 $(\mathrm{pH}<0)$, the micropore volume is reported to be about $5-8 \%$ of the overall pore volume [24]. While under present condition ( $\mathrm{pH} 2.5$ ), the contribution of microporosity to the total pore structure is increased to $6-12 \%$. Under mild acidic conditions, the rate of condensation is faster than the rate of hydrolysis of TEOS and therefore a larger number of micropores is generated in SBA-15 samples. Furthermore, the micropore $S_{\mathrm{BET}}$ and $D_{\mathrm{V}}$ of Ln-SBA15 are relatively higher than that of pure SBA-15, which confirms that the addition of lanthanide directly influences the microporous structure in framework.

\subsection{Coordination environment of lanthanide}

Fig. 4 shows the diffuse reflectance UV-vis spectra of the Ce-SBA-15 sample synthesized at $\mathrm{pH} 2.5$ with $\mathrm{Ce} / \mathrm{Si}=0.1$. For comparison purposes, the UV-vis spectra of the impregnated Ce-Im-SBA-15 $(\mathrm{Ce} / \mathrm{Si}=0.03)$ and pure $\mathrm{CeO}_{2}$ samples are also shown in Fig. 4. The two maximum adsorption peaks produced by the unsupported ceria can be credited to the specular reflectance which affects the shape of the interband transition, although not modifying the absorption peak position which appears at ca. $400 \mathrm{~nm}$ [25]. In the case of the Ce-SBA-15 and Ce-Im-SBA-15 samples, the adsorption peak shifts to $300 \mathrm{~nm}$ and $280 \mathrm{~nm}$, respectively. Other scientists have also observed these two peaks and have provided their interpretation in regards to this phenomenon. In Li's study, the absorption band centered at $300 \mathrm{~nm}$ was attributed to the metal charge

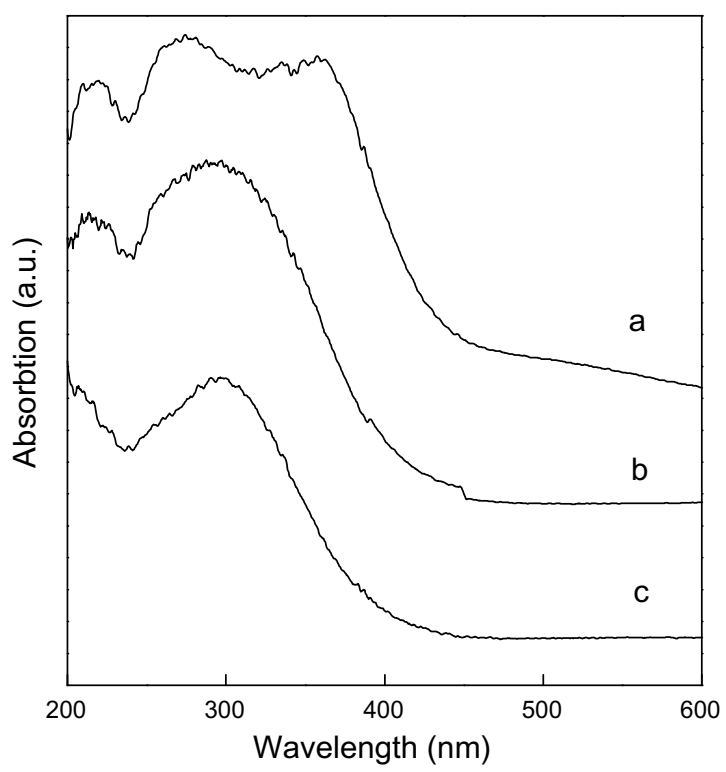

Fig. 4. Diffuse reflectance UV-vis adsorption spectra of samples: (a) $\mathrm{CeO}_{2}$; (b) Ce-Im-SBA-15 (Ce/Si = 0.03) and (c) Ce-SBA-15. 
transfer $\left(\mathrm{O}^{2-} \rightarrow \mathrm{Ce}^{4+}\right)$ of $\mathrm{CeO}_{2}$ clusters of several nanometers in size [26]. Laha characterized Ce-MCM-41 with UVvis spectra and made a conjecture that the adsorption peak at $300 \mathrm{~nm}$ was due to the presence of one type of well-dispersed $\mathrm{Ce}^{4+}$ species (presumably in a tetra-coordinated environment) [15]. Bensalem ascribed the adsorption band centered at $280 \mathrm{~mm}$ to the $\mathrm{Ce}^{4+}$-oxygen charge transfer transitions predominating in the presence of small crystallites [27]. For all the samples in our study, a weak absorption band centered at $210 \mathrm{~nm}$ was observed, which can be credited to the $4 \mathrm{f}-5 \mathrm{~d}$ inter-configuration transition of the $\mathrm{Ce}^{3+}$ species [26]. Based on the above interpretation made by Laha on the adsorption peak at $300 \mathrm{~nm}$, we cannot make a conclusive statement about the coordination state of the $\mathrm{Ce}^{4+}$ ion in the Ce-SBA-15 materials. At least we can infer that most of the $\mathrm{Ce}^{4+}$ are highly dispersed in Ce-SBA-15 from the wide-angle XRD spectrum of CeSBA-15 $(\mathrm{Ce} / \mathrm{Si}=0.1$, synthesized at $\mathrm{pH} 2.5)$ shown in Fig. 5. This is due to the intensities of the $\mathrm{CeO}_{2}$ peaks of Ce-SBA-15 being weaker than those of Ce-Im-SBA-15 $(\mathrm{Ce} / \mathrm{Si}=0.03)$ synthesized by the impregnation method, although they were synthesized using the same Ce/Si molar ratios. Thus, it can be concluded that there exist large amounts of well-dispersed isolated $\mathrm{Ce}^{4+}$ in the framework of the Ce-SBA-15 sample, or there exist cerium species in the nanometer scale that are too small to have diffraction peaks.

The FT-IR spectra of pure SBA-15 and different LnSBA-15 samples are shown in Fig. 6. In the framework region $(400-1300 \mathrm{~nm})$, the vibration band at ca. $1082 \mathrm{~cm}^{-1}$ (for pure SBA-15) is assigned to $v_{\text {as }}(\mathrm{Si}-\mathrm{O}-\mathrm{Si}$ ), while for Ln-SBA-15, this band shifts toward the lower wave number ca. $1064 \mathrm{~cm}^{-1}$. Generally speaking, this shift toward the lower wave number is considered as an indication of the incorporation of $\mathrm{Ln}$ ions into the framework of

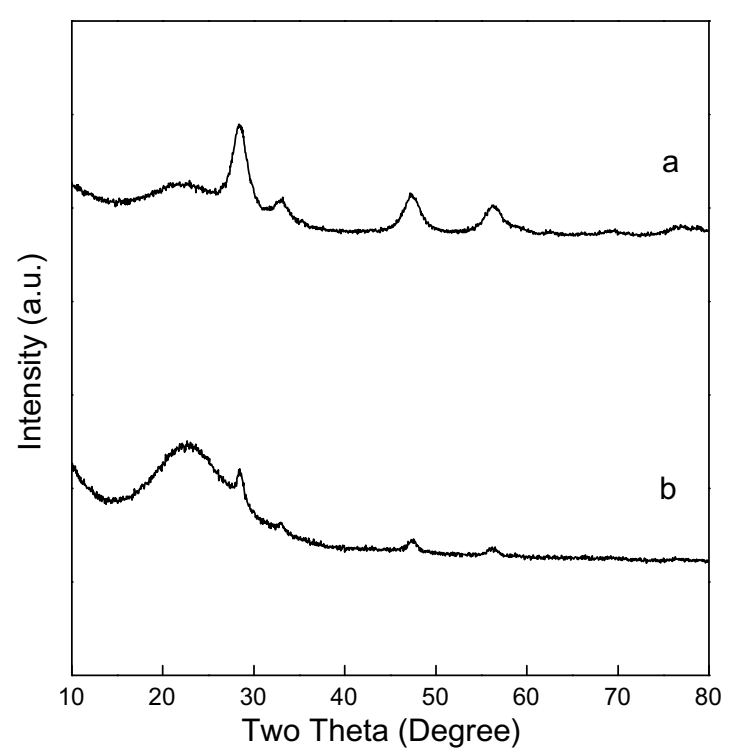

Fig. 5. XRD patterns of Ce-Im-SBA-15 (Ce/Si $=0.03)$ (a) and Ce-SBA-15 $(\mathrm{Ce} / \mathrm{Si}=0.1)$ synthesized at $\mathrm{pH} 2.5(\mathrm{~b})$.

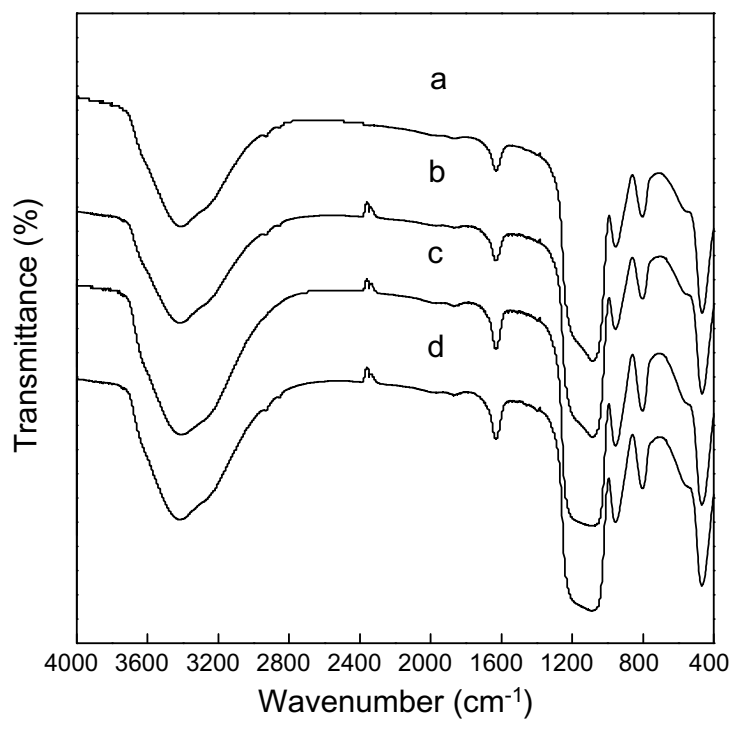

Fig. 6. FT-IR spectra of Si-SBA-15 and Ln-SBA-15 ( $\mathrm{Ln} / \mathrm{Si}=0.1)$ synthesized at pH 2.5: (a) Si-SBA-15; (b) La-SBA-15; (c) Ce-SBA-15 and (d) Nd-SBA-15.

SBA-15 [15]. For Ln-SBA-15, the band at ca. $960 \mathrm{~cm}^{-1}$ can be assigned to a $v_{\text {as }}(\mathrm{Si}-\mathrm{O}-\mathrm{Ln})$ vibration present in the framework of SBA-15 [15]. However, a band at ca. $965 \mathrm{~cm}^{-1}$ is also observed in the pure SBA-15. This band can be assigned to the $\mathrm{Si}-\mathrm{O}$ stretching vibrations of the $\mathrm{Si}-\mathrm{O}-\mathrm{R}^{+}$groups, as $\mathrm{R}^{+}=\mathrm{H}^{+}$groups are present in the calcined state [28]. Therefore, this band cannot be taken as proof of $\mathrm{Ln}$ incorporation in the framework of SBA-15 because a large number of silanol groups are always present in Si-SBA-15. It is also observed that the $v_{\mathrm{as}}(\mathrm{Si}-\mathrm{O}-$ $\mathrm{Ln})$ and/or $v(\mathrm{Si}-\mathrm{OH})$ band intensity increases with respect

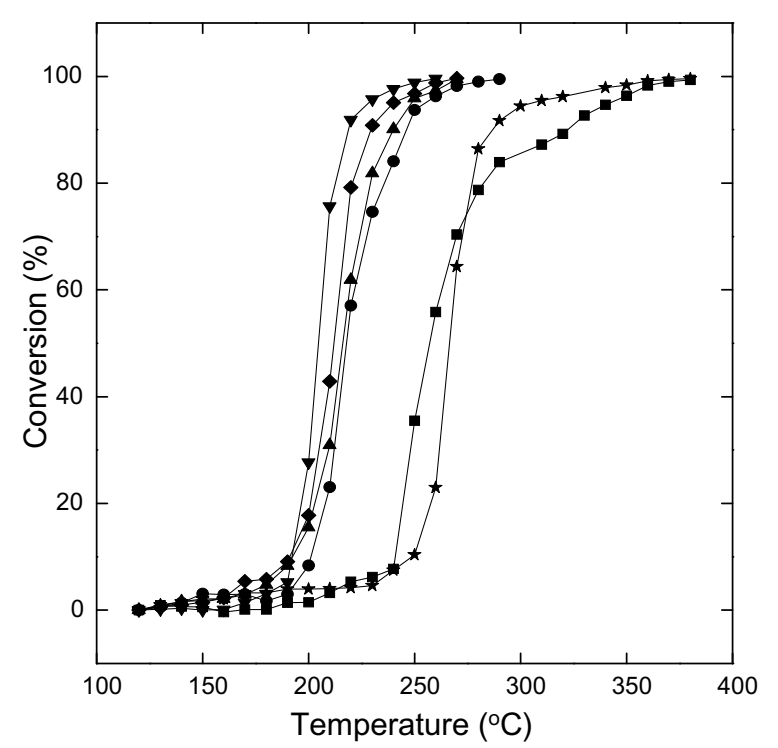

Fig. 7. Benzene conversion on Pd catalysts over Ln-containing supports with $\mathrm{Ln} / \mathrm{Si}=0.1$ ( $\boldsymbol{\nabla}) \mathrm{Pd} / \mathrm{Nd}-\mathrm{SBA}-15$; ( $) \mathrm{Pd} / \mathrm{La}-\mathrm{SBA}-15$; ( $\mathbf{\Delta}$ ) Pd/Ce-SBA15; (ם) Pd/Ce-Im-SBA-15 and no Ln-containing supports $(\bullet)$ Pd/SBA-15

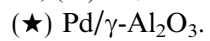


Table 3

Activity data of the samples in the catalytic oxidation of benzene

\begin{tabular}{llll}
\hline Samples & $T_{10}\left({ }^{\circ} \mathrm{C}\right)$ & $T_{50}\left({ }^{\circ} \mathrm{C}\right)$ & $T_{90}\left({ }^{\circ} \mathrm{C}\right)$ \\
\hline $\mathrm{Pd} / \gamma-\mathrm{Al}_{2} \mathrm{O}_{3}{ }^{\mathrm{a}}$ & 250 & 267 & 288 \\
$\mathrm{Pd} / \mathrm{Ce}-\mathrm{Im}-\mathrm{SBA}-15^{\mathrm{b}}$ & 241 & 257 & 324 \\
$\mathrm{Pd} / \mathrm{SBA}-15^{\mathrm{c}}$ & 201 & 218 & 246 \\
$\mathrm{Pd} / \mathrm{La}-\mathrm{SBA}-15$ & 192 & 212 & 229 \\
$\mathrm{Pd} / \mathrm{Ce}-\mathrm{SBA}-15$ & 193 & 216 & 239 \\
$\mathrm{Pd} / \mathrm{Nd}-\mathrm{SBA}-15$ & 192 & 204 & 219 \\
\hline
\end{tabular}

${ }^{\mathrm{a}} \gamma-\mathrm{Al}_{2} \mathrm{O}_{3}$ is a Commercial product.

b,c Ce-Im-SBA-15 was Ce impregnated Im-SBA-15 with $\mathrm{Ce} / \mathrm{Si}=0.03$.

to that of $v_{\text {as }}(\mathrm{Si}-\mathrm{O}-\mathrm{Si})$ and/or $v(\mathrm{Si}-\mathrm{OH})$ band when $\mathrm{Ln}$ are incorporated. This may be taken as an evidence of the incorporation of the Ln metal into the framework of mesoporous materials. In all spectra, the band at ca. $800 \mathrm{~cm}^{-1}$ is assigned to the symmetric $\mathrm{Si}-\mathrm{O}-\mathrm{Si}$ stretching vibration [29-31]. In the hydroxyl region $\left(3000-4000 \mathrm{~cm}^{-1}\right)$, the adsorption band at $3420 \mathrm{~cm}^{-1}$ for all the samples is attributed to the stretching vibrations of the silanol groups interacting via hydrogen bonding [32].

\subsection{Catalytic activity}

The catalytic oxidation of benzene was carried out using different Pd/Ln-SBA-15 samples. For comparison reasons, $\mathrm{Pd} / \mathrm{SBA}-15, \mathrm{Pd} / \mathrm{Ce}-\mathrm{Im}-\mathrm{SBA}-15$ and $\mathrm{Pd} / \gamma-\mathrm{Al}_{2} \mathrm{O}_{3}$ were also used to measure their catalytic activities. The results are shown in Fig. 7. It is observed that Ln-SBA-15 supported $\mathrm{Pd}$ catalysts show higher catalytic activities than SBA-15, $\gamma-\mathrm{Al}_{2} \mathrm{O}_{3}$ and $\mathrm{Ce}-\mathrm{Im}-\mathrm{SBA}-15$ supported $\mathrm{Pd}$ catalysts. The activity data of the catalysts tested are listed in Table 3. Among the catalysts, Pd/Nd-SBA-15 shows the best catalytic performance, for which $90 \%$ oxidation of benzene is achieved at $219^{\circ} \mathrm{C}$. Although the value of $T_{10}$ (the temperature at which the benzene conversion reached $10 \%$ ) is similar for Pd/Ln-SBA-15 in the reaction, $T_{90}$ (the temperature at which the benzene conversion reached $90 \%$ ) for $\mathrm{Pd} / \mathrm{La}-$ SBA-15 and Pd/Ce-SBA- 15 is $229^{\circ} \mathrm{C}$ and $239^{\circ} \mathrm{C}$ respectively, which is lower than that of Pd/Nd-SBA-15. $T_{90}$ for Pd/SBA- 15 is about $250{ }^{\circ} \mathrm{C}$ and $100 \%$ oxidation of benzene is achieved at $300{ }^{\circ} \mathrm{C}$. Whereas for Pd/Ln-SBA-15, the temperatures at which benzene are completely converted are found at about $260{ }^{\circ} \mathrm{C}$. This decrease of $T_{100}$ can be attributed to the incorporation of lanthanide into SBA15 , which is seen as an advantage as it enhances the catalytic activity of catalysts. The importance of lanthanide in promoting oxidation reactions of VOCs has been previously reported [33-36]. As shown in Fig. 7, the 100\% conversion of benzene for $\mathrm{Pd} / \gamma-\mathrm{Al}_{2} \mathrm{O}_{3}$ and $\mathrm{Pd} / \mathrm{Ce}-\mathrm{Im}-\mathrm{SBA}-15$ was obtained at $400{ }^{\circ} \mathrm{C}$, with $T_{10}$ of $250^{\circ} \mathrm{C}$ and $240{ }^{\circ} \mathrm{C}$ respectively. It should be noted that the Pd/Ce-Im-SBA15 shows the poorest performance in the catalytic oxidation of benzene from $270{ }^{\circ} \mathrm{C}$ to $400{ }^{\circ} \mathrm{C}$. The activity of Ceria-based catalyst is known to strongly depend on its structure. Nanosized ceria shows higher activity than that of bulk-phase ceria, because of the easier reduction of the surface oxygen species on ceria nanoparticles $[37,38]$. Thus, it can be concluded that Ce-SBA-15 synthesized in this work shows better activity than Ce-Im-SBA-15 as a catalyst support which is probably due to the presence of large amounts of well-dispersed $\mathrm{Ce}^{4+}$ species in the Ce-SBA-15 material, as previously discussed in Section 3.3.

\section{Conclusions}

In summary, lanthanide-containing SBA-15 materials La-SBA-15, Ce-SBA-15 and Nd-SBA-15 materials have been successfully synthesized using a direct synthesis method under weak acidic conditions. The initial $\mathrm{pH}$ of the $\mathrm{HCl}$ solution plays an important role in the preparation of well-dispersed and ordered Ln-containing SBA-15 materials and must be strictly controlled between 1.5 and 3.0. The addition of Lanthanide nitrate also favors the ordering of the mesoporous structure of the materials due to their salt effect. In the catalytic characterization, the Ln-SBA15 supported Pd catalysts show higher catalytic activity than other catalysts prepared in our laboratory by the impregnation method, which is notably higher than that of Pd/Ce-Im-SBA-15. It further testifies the advantage of using the direct synthesis method in the preparation of highly dispersed heteroatom-containing materials. This type of Ln-SBA-15 materials shows great potential as support in the catalytic reactions, such as in the catalytic oxidation of VOCs originated from industrial emissions.

\section{Acknowledgments}

National Basic Research Program of China (2004CB719500), High Technology Research and Development Program of China (2006AA06A310) and National Science Fund for Distinguished Young Scholars (20725723) are gratefully acknowledged.

\section{References}

[1] J.S. Beck, J.C. Vartuli, W.J. Roth, M.E. Leonowicz, C.T. Kresge, K.D. Schmitt, C.T.-W. Chu, D.H. Olson, E.W. Sheppard, S.B. McCullen, J.B. Higgins, J.L. Schlenker, J. Am. Chem. Soc. 114 (1992) 10834.

[2] J.S. Tanev, T.J. Pinnavaia, Science 267 (1995) 865.

[3] S. Inagaki, Y. Fukushima, K. Kuroda, Chem. Commun. (1993) 680.

[4] R. Ryoo, J.M. Kim, C.H. Shin, J.Y. Lee, Stud. Surf. Sci. Catal. 105 (1997) 45.

[5] A. Vinu, V. Murugesan, W. Böhlmann, M. Hartmann, J. Phys. Chem. B 108 (2004) 11496.

[6] W. Zhang, J. Lu, B. Han, M. Li, J. Xiu, P. Ying, C. Li, Chem. Mater. $14(2002) 3413$

[7] Y. Li, Z. Feng, Y. Lian, K. Sun, L. Zhang, G. Jia, Q. Yang, C. Li, Micropor. Mesopor. Mater. 84 (2005) 41.

[8] S. Chen, L. Jang, S. Cheng, Chem. Mater. 16 (2004) 4174.

[9] M. Robert, J. Willian, Chem. Commun. (1997) 2185.

[10] Z. Luan, M. Hartmann, D. Zhao, W. Zhou, L. Kevan, Chem. Mater. 11 (1999) 1621

[11] P. Kustrowski, L. Chmielarz, R. Dziembaj, P. Cool, E.F. Vansant, J. Phys. Chem. B. 109 (2005) 11552. 
[12] B.L. Newalkar, J. Olanrewaju, S. Komarneni, Chem. Mater. 13 (2001) 552 .

[13] Y. Wang, Z. Wu, Y. Wei, J. Zhu, Micropor. Mesopor. Mater. 84 (2005) 127.

[14] I. Otheman, R.M. Mohamed, I.A. Ibrahim, M.M. Mohamed, Appl. Catal. A. 299 (2006) 9.

[15] S.C. Laha, P. Mukherjee, S.R. Sainkar, R. Kumar, J. Catal. 207 (2002) 213.

[16] J. Sauer, F. Marlow, B. Spliethoff, F. Schüth, Chem. Mater. 14 (2002) 217.

[17] Y. Li, W. Zhang, L. Zhang, Z. Wei, Q. Yang, Z. Feng, C. Li, J. Phys. Chem. B 108 (2004) 9739.

[18] D.Y. Zhao, Q.S. Huo, J.L. Feng, B.F. Chmelka, G.D. Stucky, J. Am. Chem. Soc. 120 (1998) 6024.

[19] Y. Kuang, N. He, J. Wang, P. Xiao, C. Yuan, Z. Lu, Colloid Surf. A - Physicochem. Eng. Asp. 179 (2001) 177.

[20] A. Tuel, S. Gontier, Chem. Mater. 8 (1996) 2014.

[21] H.-P. Lin, C.-P. Mou, S.-B. Liu, J. Phys. Chem. B 104 (2000) 7885.

[22] J.N. Israelachvili, D.J. Mitchell, B.W. Ninham, J. Chem. Soc., Faraday Trans. B 72 (1976) 1525.

[23] S.J. Gregg, K.S.W. Sing, Adsorption, Surface Area, and Porosity, Academic Press, London, 1982.

[24] P.I. Ravikovitch, A.V. Neimark, Langmuir 18 (2002) 9830.

[25] A. Bensalem, F. Bozon-Verduraz, M. Delamar, G. Bugli, Appl. Catal. A 121 (1995) 81.
[26] Z. Li, M. Flytzani-Stephanopoulos, J. Catal. 182 (1999) 313.

[27] A. Bensalem, J.C. Muller, F. Bozon-Verduraz, J. Chem. Soc., Faraday Trans. 88 (1992) 153.

[28] M. Decottiguies, J. Phalippou, J. Zarzycki, J. Mater. Sci. 13 (1978) 2605.

[29] G.A. Eimer, L.B. Pierella, G.A. Monti, O.A. Anunizata, Catal. Lett. 78 (2002) 65.

[30] M.S. Wong, H.C. Huang, J.Y. Ying, Chem. Mater. 14 (2002) 1961.

[31] Z. Shan, E. Gianotti, J.C. Jansen, J.A. Peters, L. Marchese, T. Maschmeyer, Chem. Eur. J. 7 (2001) 1437.

[32] M. Stockenhuber, M.J. Hudson, R.W.J. Joyner, J. Phys. Chem. B 104 (2000) 3370.

[33] M.A. Centeno, P. Malet, I. Carrizosa, J.A. Odriozola, J. Phys. Chem. B 104 (2000) 3310.

[34] S. Scirè, S. Minicò, C. Crisafulli, C. Satriano, A. Pistone, Appl. Catal. B 40 (2003) 29.

[35] S. Minicò, S. Scirè, C. Crisafulli, R. Maggiore, S. Galvagno, Appl. Catal. B 28 (2000) 245.

[36] V. Idakiev, L. Ilieva, D. Andreeva, J.L. Blin, L. Gigot, B.L. Su, Appl. Catal. A 243 (2003) 25.

[37] Y.-W. Zhang, R. Si, C.-S. Liao, C.-H. Yan, C.-X. Xiao, Y. Kou, J. Phys. Chem. B 107 (2003) 10159.

[38] H. Cordatos, T. Bunluesin, J. Stubenrauch, J.M. Vohs, R.J. Gorte, J. Phys. Chem. 100 (1996) 785. 